\title{
Performance of metal compound on thermolysis and electrolysis on sugar industries waste water treatment: COD and color removal with sludge analysis (batch-experiment)
}

\author{
Omprakash Sahu ${ }^{1}$
}

Received: 2 March 2016/ Accepted: 17 May 2016/Published online: 21 June 2016

(c) The Author(s) 2016. This article is published with open access at Springerlink.com

\begin{abstract}
The sugar cane industry is one of the most water demanding industries. Sugar industries consume and generate excess amount of water. The generated water contains organic compounds, which would cause pollution. The aim of this research work is to study the effectiveness of metal compound for treatment of sugar industry waste water by thermolysis and electrolysis process. The result shows ferrous metal catalyst shows 80 and $85 \%$ chemical oxygen demand and color removal at $\mathrm{pH} 6$, optimum mass loading $4 \mathrm{~kg} / \mathrm{m}^{3}$, treatment temperature $85^{\circ} \mathrm{C}$ and treatment time $9 \mathrm{~h}$. When ferrous material was used as electrode, maximum $81 \%$ chemical oxygen demand and $84 \%$ color removal at $\mathrm{pH} 6$, current density $156 \mathrm{Am}^{-2}$, treatment time $120 \mathrm{~min}$ and anode consumption $0.7 \mathrm{~g}$ for $1.5 \mathrm{~L}$ wastewater were obtained.
\end{abstract}

Keywords Catalyst - Electrolysis · Oxidation - Metal · Sludge . Thermal treatment

\section{Introduction}

In the year of 2014-15 sugarcane has been planted in 5.03 million hectares area by India (ISMA 2015). Indian sugar consumption is forecast to rise to 27 million metric tons in 2014-15, because of continued strong domestic demand (Aradhey 2015). Sugar industry has a significant impact on country's economic development. The industries have also major contribution in increasing the water pollution

Omprakash Sahu

ops0121@gmail.com

1 School of Chemical and Food Engineering BiT, Bahir Dar University, Bahir Dar, Ethiopia (Africa)
(Saranraj and Stella 2014). Sugar industry wastewaters are produced mainly by cleaning operations. Washing of milling house floor, various division of boiling house like evaporators, clarifiers, vacuum pans, centrifugation, etc., generates huge volume of wastewater. Also, wash water used for filter cloth of rotary vacuum filter and periodical cleaning of lime water and $\mathrm{SO}_{2}$ producing house becomes a part of wastewater (Kushwaha 2013). The elemental pollutant present in the sugar industry effluents are phosphates, nitrogen in the form of nitrates, various volatile solids, high TDS and suspended solids, various organic pollutants with high COD level (Tripathi et al. 2014). In proper treatment of wastewater bring unpleasant odors, effect on flora, fauna and human health (Sahu and Chaudhari 2015). Although all the industries function under the strict guidelines of the Pollution Control Agencies of the country, the environmental pollution situation is far from satisfactory especially in poor and developing countries. Different norms and guidelines are given for all the industries depending upon their pollution creating aspects (Gupta and Garg 2014). Most of the major industries have treatment facilities for industrial effluents. The treatment efficiency depends upon process and technique adopted according to pollution level (Yadav et al. 2014). Some methods have been already introduced to treat the waste water by using the metals, salts and oxide or combinations of iron, aluminium copper, etc. (Shivayogimath and Jahagirdar 2013). Among them iron is cheap, easily available and mostly used in water and wastewater treatment (Genther and Beede 2013; Upadhyay and Mistry 2012) in coagulation process (Farajnezhad and Gharbani 2012), electrocoagulation process (Ulucan et al. 2014) and in thermal treatment as catalyst (Verma et al. 2011). In the literature electrocoagulation and thermolysis is more popular among environmentalists to treat the different 
industrial wastewater like pulp and paper waste water (Mahesh et al. 2006), textile waste water (Essadki et al. 2008), drugs waste water (Deshpande and Satyanarayan 2011), petroleum industry (Verma et al. 2011), etc. The main aim of research work is to examine the performance of iron metal and salt for the treatment of sugar industry wastewater water treatment. The studies focus on effects of initial $\mathrm{pH}$, massloading and working temperature on removal efficiency. Generated sludge has been analyzed with settling, filtration FTIR and scanning electron micrograph.

\section{Materials and methods}

\section{Material}

The waste water used for experiments was arranged from Bhoramdev Sugar Industry Ltd. Kavardha (C.G.) India. The characteristics of effluent are presented in Table 1. The waste water was preserved at $4{ }^{\circ} \mathrm{C}$ untilled experiment. Analytical grade chemical of Merck Limited, Mumbai India, were used for analysis.

\section{Experimental methods}

The electrocoagulation experiments were conducted for treatment of sugar effluent in batch method. Electrochemical treatment of both anionic and cationic species is possible by using an iron plate/rod as the sacrificial electrode. The electrode plates were cleaned manually with sandpaper and they were treated with $15 \% \mathrm{HCL}$ for cleaning followed by washing with distilled water prior to their use. The electrodes were spaced $20 \mathrm{~mm}$ a part. The anode and the cathode were connected to the respective terminals of DC power supply. Current varies from 1 to $5 \mathrm{~A}$ and measured with an ammeter. A voltage varies from 0 to $25 \mathrm{~V}$ and measured with a voltmeter.

For the thermolysis process, a glass reactor was used for the thermolysis experiments at atmospheric pressure. This glass reactor (AGR) is a spherical vessel (capacity $0.5 \mathrm{dm}^{3}$ ) equipped with a temperature indicator cum controller, a long vertical condenser for condensing the vapor, and a magnetic stirrer with variable speed for stirring the reactor contents. The temperature of the reaction mixture during thermal pretreatment operations was maintained between 55 and $95{ }^{\circ} \mathrm{C}$. The amount of wastewater $(\mathrm{COD} 0=3682 \mathrm{mg} / \mathrm{l})$ taken in each run was $300 \mathrm{ml}$. The catalytic agents in desired concentration were used during the operation. Five milliliters of the sample were withdrawn at a definite interval of time and analyzed for its $\mathrm{COD}$ and color. The initial $\mathrm{pH}$ of the wastewater was varied between 2 and 10 by using either $0.1 \mathrm{~N} \mathrm{HCl}$ or $1 \mathrm{M}$
Table 1 Physicochemical parameters of sugar industry wastewater

\begin{tabular}{lll}
\hline S. no. & Characteristics & Before treatment \\
\hline 1 & Color & Dark yellow \\
2 & pH change & 5.5 \\
3 & COD & 3682 \\
5 & Phosphate & 5.9 \\
6 & Protein & 43 \\
7 & Total solid & 1287 \\
8 & Suspended solid & 340 \\
9 & Dissolved solid & 947 \\
10 & Chloride & 50 \\
11 & Hardness & 900 \\
\hline
\end{tabular}

Except $\mathrm{pH}$ and color all values are in $\mathrm{mg} / \mathrm{l}$

$\mathrm{NaOH}$. The experiments were carried out in two different ways which are shown in Fig. 1. Percentage of COD and color are determined by Eq (1):

$\operatorname{Removal}(\%)=\frac{\left(X_{1}-X_{2}\right) \times 100}{X_{1}}$,

where is $X_{1}=$ initial value and $X_{2}=$ final value.

\section{Analytical procedure}

The COD of the samples was determined by the standard dichromate reflux method (Holt et al. 1999). The chloride concentration was determined by the standard titrimetric Volhard method (Vogel 1958). Sulfates and the phosphates were determined by using standard methods (Holt et al. 1999). The concentrations of the metal ions in the filtrate and the residue were determined by using an atomic absorption spectrometer (GBC, Model Awanta, Australia). The protein content was determined by the Bradford (1976) method. The color of the sample was measured in terms of the absorbance at $\lambda=420 \mathrm{~nm}$ using a UV-vis spectrophotometer (Model Lambda 35) from Perkin-Elmer Instruments, Switzerland. The residual organics in the treated effluent were analyzed by Fourier transform infrared (FT-IR) spectroscopy (Bruker optics, VERTEX80).

\section{Results and discussion}

\section{pH optimization}

To examine the effect of $\mathrm{pH}$ on SIWW by using $\mathrm{FeSO}_{4}$, $\mathrm{CuSO}_{4}$ and without salt for thermal oxidation, and iron and aluminium electrode for electro-oxidation process has been carried out at initial $\mathrm{pH} 2-10$, which is shown Fig. 2a, b. It was observed that $\mathrm{FeSO}_{4}$ shows maximum COD $55 \%$ and 


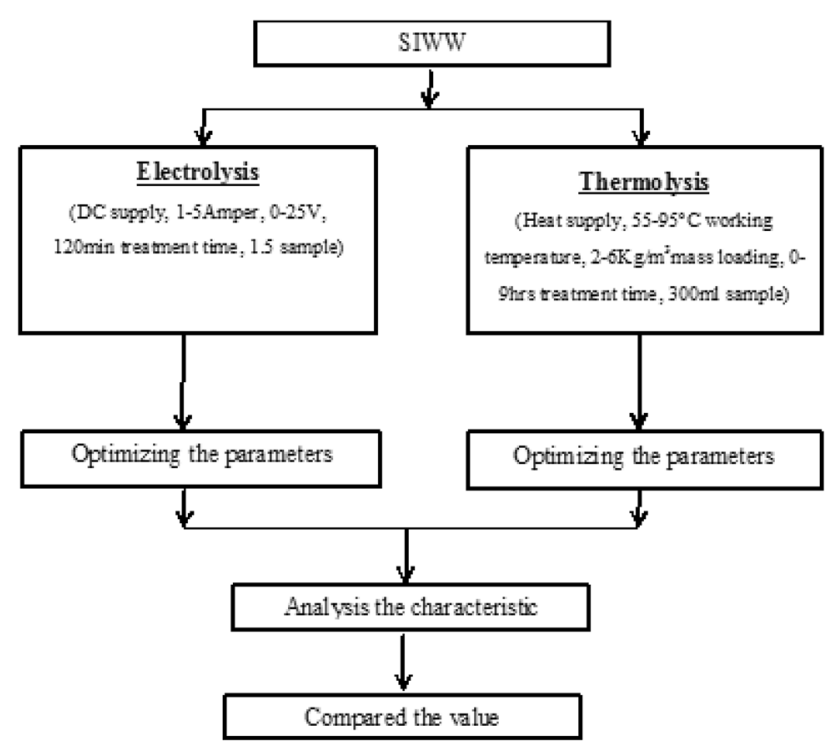

Fig. 1 Experimental performances

color $61 \%$ reduction at $\mathrm{pH} 6$ as compared to this $\mathrm{CuSO}_{4}$ shows maximum COD48 \% and color $54 \%$ percentage reduction at $\mathrm{pH} 4$. When effluent was treated without catalysis it shows $34 \%$ COD and $42 \%$ of color reduction at $\mathrm{pH} 10$. All the experiments for thermolysis were carried out at $65{ }^{\circ} \mathrm{C}$, initial mass loading at $3 \mathrm{~kg} / \mathrm{m}^{3}$, time $9 \mathrm{~h}$ and CODo was $3682 \mathrm{mg} / \mathrm{l}$. The thermochemical precipitation (or thermolysis) undergoes complex reactions over the reaction time, thereby affecting the $\mathrm{pH}$ of the reactor mass. The compounds probably undergo hydrolysis to a limited extent with the formation of small amounts of lower carboxylic acids (Kumar et al. 2009). The effect of initial pH on electrolysis was carried out at $\mathrm{pH} 2-10,20 \mathrm{~mm}$ electrode distance and $2 \mathrm{~A}$ current. From the experiment it was observed that iron electrode shows maximum $64 \%$ COD and $70 \%$ color reduction at $\mathrm{pH} 6$ and at similar parameter $\mathrm{Al}$ electrode shows $60 \% \mathrm{COD}$ and $71 \%$ color reduction at $\mathrm{pH}$ 7. This is might be due to aluminium and iron cations and hydroxides causing destabilization of colloids. Effective coagulant species are formed in acidic, neutral and slightly alkaline $\mathrm{pH}$. In highly alkaline $\mathrm{pH}, \mathrm{Al}(\mathrm{OH})_{4}$ and $\mathrm{Fe}(\mathrm{OH})_{4}$ ions are formed and these ions have poor coagulation performance (Behbahani et al. 2011).

\section{Mass loading and current density}

The effects of mass loading of ferrous sulfate on thermolysis process (weight) and ferrous metal for electrocoagulation process (current density) were carried out at optimum and are shown in Fig. 3a, b. In thermal process maximum COD $64 \%$ and color $70 \%$ reduction was observed at mass loading $4 \mathrm{~kg} / \mathrm{m}^{3}$, that is considered to be optimum. When mass loading was $2 \mathrm{~kg} / \mathrm{m}^{3}$ and $3 \mathrm{~kg} / \mathrm{m}^{3}$, COD $43,55 \%$ and color $50,61 \%$ reduction was found. The COD 58, $52 \%$ and color removal $65,60 \%$ were also poor at $5 \mathrm{~kg} / \mathrm{m}^{3}$ and $6 \mathrm{~kg} / \mathrm{m}^{3}$ (Fig. 2a). It may be due to under-dosing catalysts are not sufficient to bring the reaction and at overdosing more reaction was occurred. This result is similar with petrochemical waste water treatment by thermolysis (Verma et al. 2011). The current density is another important parameter for pollutant removal in the electrocoagulation; it gives the dissolution rate of metal hydroxide concentration formed during the process. The effect was investigated by varying the applied current density in the range of 39 to $195 \mathrm{~A} / \mathrm{m}^{2}$ at 120 min treatment time, optimum pH 6 and electrode distance $20 \mathrm{~mm}$. It was observed that COD 51, 64, $72 \%$ and color 62, 70, $76 \%$ reduction was increased with the increase in current density 39, 78, $117 \mathrm{~A} / \mathrm{m}^{2}$. The maximum $82 \% \mathrm{COD}$ and $84 \%$ color reduction found at $156 \mathrm{~A} / \mathrm{m}^{2}$, then a decrease to $76 \% \mathrm{COD}$ and $80 \%$ color was found for maximum CD $195 \mathrm{~A} / \mathrm{m}^{2}$. It is well known that electrical current not only determined the coagulant dosage rate, but also the bubble production rate and size and the floc growth, which can influence the treatment efficiency of the electrocoagulation (Vinodha et al. 2012). High current density especially causes both decomposition of the electrode material and an increase in pollutant removal (Kobya et al. 2006). A relation between addition of ion per unit volume with current density and time can be determined by Faraday's Law. The weight losses in anode increase with increase in current density $0.7 \mathrm{~g}$ of iron electrode losses was observed at $4 \mathrm{~A}$ current supply. This was attributed to high current densities; the extent of anodic dissolution increased and in turn the amount of hydroxo-cationic complexes resulted in an increase of the color and COD removal. The highest allowable current density may not be the most efficient mode of running the reactor. It is well known that the optimal current density will invariably involve a trade-off between operational costs and efficient use of solution $\mathrm{pH}$, temperature, flow rate, etc. (Liu et al. 2010).

\section{Effect of temperature}

The COD and color reduction were also observed with respect to time for both thermolysis and electrolysis, which are shown in Fig. 4a-c. To optimize the effect of temperature on thermolysis reaction was carried from 55 to $95{ }^{\circ} \mathrm{C}$ at optimum mass loading $4 \mathrm{~kg} / \mathrm{m}^{3}$ and optimum $\mathrm{pH}$ 6. The percent reductions of COD and color increased as the temperature increased from 55 to $85{ }^{\circ} \mathrm{C}$ and time $0-9 \mathrm{~h}$. The percent COD reduction (maximum) at $85{ }^{\circ} \mathrm{C}$ obtained was $80 \%$, at which the percent color reduction was $85 \%$ at $9 \mathrm{~h}$, respectively. After that increase in temperature 
Fig. 2 Effect of initial $\mathrm{pH}$ on COD and color removal: a thermolysis at $65^{\circ} \mathrm{C}$, initial mass loading at $3 \mathrm{~kg} / \mathrm{m}^{3}$, time $9 \mathrm{~h}$; b electrolysis at $2 \mathrm{~A}$ current, $20 \mathrm{~mm}$ electrode distance $($ CODo $=3986 \mathrm{mg} / \mathrm{l})$
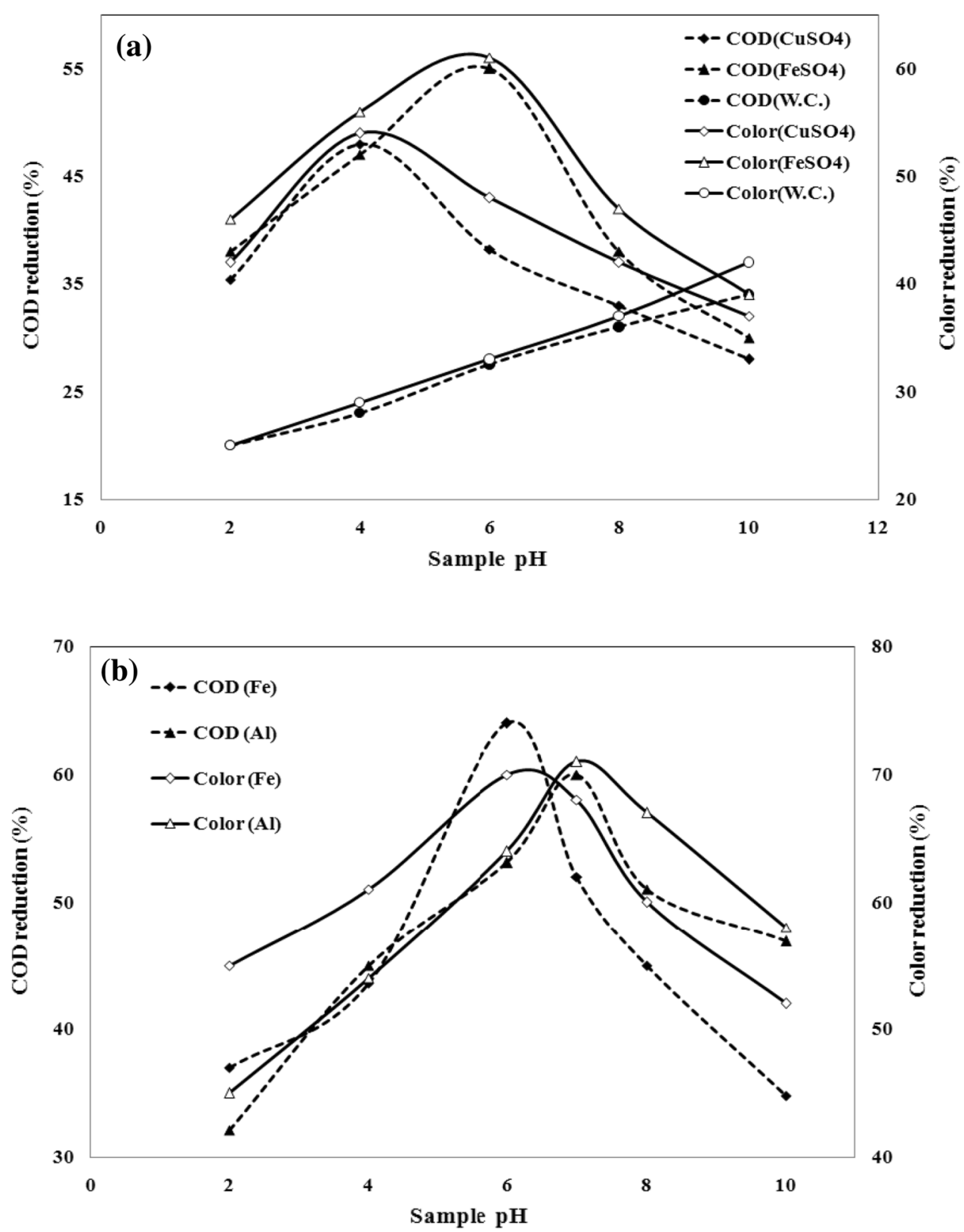

$95{ }^{\circ} \mathrm{C}$ decreases in COD $70 \%$ and color $76 \%$ reduction, respectively (Fig. 3a). Since the experiment was conducted at atmospheric pressure (in a glass reactor under reflux), the reaction temperature did not exceed beyond $95^{\circ} \mathrm{C}$ (Chaudhari et al. 2008). With increase in time 0, 1, 3, 6, $9 \mathrm{~h}$ the COD 53, 57, 68, 74, $80 \%$ and color 55, 60, 70, 76, $82 \%$ reduction was increased at fixed temperature $85^{\circ} \mathrm{C}$. This might be due to thermolysis process precipitation and thermal degradation of organic molecules that take place with respect to time (Fig. 3b). The large molecules of the organic matter break into smaller molecules which along with catalytic complexation and carbon sequestration lead to carbon-enriched solid residue formation. Kumar et al. (2008) observed similar phenomena where the reduction of COD was observed during the pre-heating period in the absence of oxygen.

The effect of time on temperature was also carried out at $156 \mathrm{~A} / \mathrm{m}^{2}, 20 \mathrm{~mm}$ electrode distance and optimum $\mathrm{pH} 6$ for $120 \mathrm{~min}$ for iron electrode (Fig. 3c). It was found that during the electrolysis process temperature 29, 35, 41, 50, $58,65{ }^{\circ} \mathrm{C}$ increase with operating time from 20 to $120 \mathrm{~min}$, respectively. The COD 38, 46, 57, 65, 73, $81 \%$ and color $42,51,60.5,68.5,76,84 \%$ were observed in $20,40,60$, 80,100 and $120 \mathrm{~min}$ of operating time. The temperature 

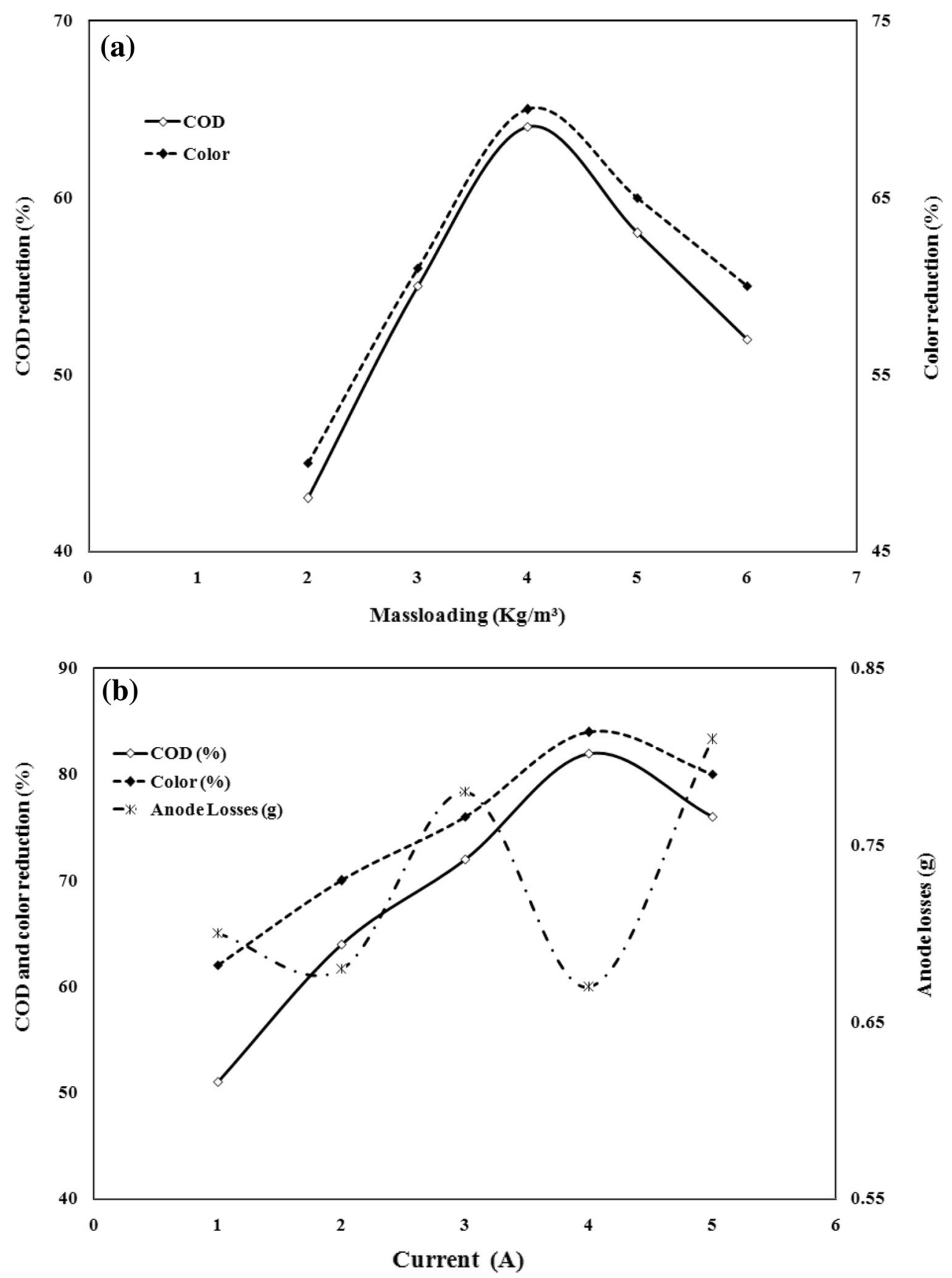

Fig. 3 Effect of mass loading on COD and color removal: a thermolysis at $65{ }^{\circ} \mathrm{C}$, optimum pH 6, time $9 \mathrm{~h}$; b electrolysis at optimum pH 6 , $20 \mathrm{~mm}$ electrode distance $(\mathrm{CODo}=3986 \mathrm{mg} / \mathrm{l})$

influence can be attributed to the increased destruction of the iron oxide film on the anode surface and the increased rate of all reactions involved in the process according to the Arrhenius equation (Chen et al. 2000). Increased temperature promoted the generation of metal hydroxides formed in the electrocoagulation process, which led to greater mobility and more frequent collisions of species, resulting in an increased reaction rate of the metal hydroxides (i.e., iron hydroxides) with pollutants (Adhoum and Monser 2004).

\section{Solid-liquid separation}

Settling Preliminary settling process is a natural treatment method that requires no chemical addition. Although some workers realized the importance of the natural 
Fig. 4 Effect of temperature on COD and color removal:

a thermolysis at $65^{\circ} \mathrm{C}$,

optimum $\mathrm{pH} 6$, time $9 \mathrm{~h}$;

b thermolysis at maximum temperature $95{ }^{\circ} \mathrm{C}$;

c electrolysis at optimum $\mathrm{pH} 6$,

$20 \mathrm{~mm}$ electrode distance $(\mathrm{CODo}=3986 \mathrm{mg} / \mathrm{l})$
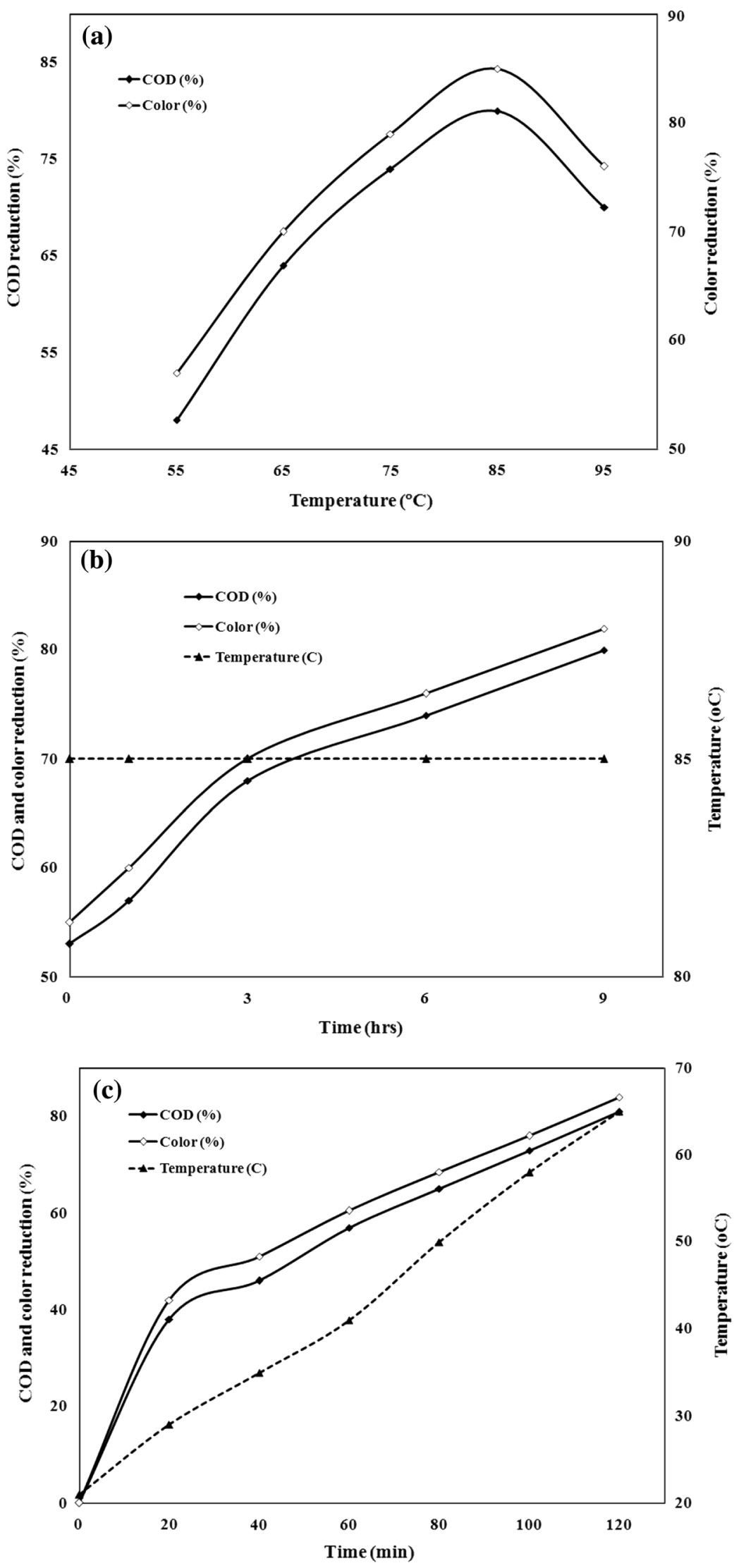
settling process, there is little information available in the literature on the effect of the preliminary settling time on pollutants removal capacity. Figure 5 shows the timecourse of the settling of sludge in terms of dimensionless height of the solid-liquid interface $\left(\mathrm{H} / \mathrm{H}_{0}\right)$ as a function of settling time at different initial system $\mathrm{pH}_{0}$. At the beginning, a very short period of relatively slow sludge settling is seen primarily because of the Brownian motion of the particles. This is followed by a steady-state decrease in the height of the solid/liquid interface, exhibiting the regime of zone settling. Thereafter, the transition settling period ensues. Finally, a steady-state compression settling takes place with a much smaller rate of decrease in the height of the interface between the sludge and the supernatant. The interface is easily identifiable for the EC-treated water and thermolysis-treated wastewater with iron salt. The waste water treated by electrocoagulation with iron shows $90 \%$ of settling in 60 min. Similarly thermolysis treated show $75 \%$ of settling in $90 \mathrm{~min}$, further increase in time up to $210 \mathrm{~min}$, will not bring any change in settling. The good settling characteristic of iron with electrocoagulation process may be due under acidic $\mathrm{pH}$; the electrode is attacked by $\mathrm{H}^{+}$ ions which enhance the Fe dissolution. The characteristic of obtained sludge is presented in Table 2.

Filterability The filtration efficiency of obtained sludgeslurry can be studied by using either a plate and frame filter or a rotary vacuum filter (Mahesh et al. 2006). For experimental data gravity filtration can also be used. Gravity filtration can be considered as a constant pressure filtration by neglecting the effect of change in the hydrostatic head on the total pressure. The force balance for the gravity filtration using a filter paper on a Buechner funnel can be written as (MaCabe et al. 1993).

$\frac{\Delta t}{\Delta V}=\frac{\mu}{A \Delta P}\left(\frac{\alpha C V}{A}+R_{m}\right)$ or

where $\Delta t$ is the time interval of filtration (s), $\Delta V$ is the filtrate volume collected up to that time interval $\Delta \mathrm{t}\left(\mathrm{m}^{3}\right)$, $C$ is the solids concentration in the slurry, $\left(\mathrm{kg} / \mathrm{m}^{3}\right), V$ is the total liquid filtrate volume collected up to the time interval $t\left(\mathrm{~m}^{3}\right), \mu$ is the viscosity of the liquid filtrate $(\mathrm{Pa} \mathrm{s}), \Delta P$ is the pressure drop across the filter $=\rho g h(\mathrm{~Pa}), A$ is the filtration area $\left(\mathrm{m}^{2}\right), R_{m}$ is the resistance of the filter medium $\left(\mathrm{m}^{-1}\right)$ and $\alpha$ is the specific resistance to filtration, also called as SCR.

After recording the observations on the volume of the filtrate as a function of time, a plot of $\Delta t / \Delta V$ may produce a straight line, which is shown in Fig. 6. The values of $R_{m}$ and $\alpha$ can be calculated from the slope and the intercept, respectively, are given in Table 3 . The value of cake resistance $2.24 \times 10^{-14} \mathrm{~m} / \mathrm{kg}$ and filter medium resistance $5.72 \times 10^{-12}$ is more for electrolysis-treated wastewater as compared to cake resistance $0.697 \times 10^{-12} \mathrm{~m} / \mathrm{kg}$ and medium resistance $3.61 \times 10^{-14}$ for thermolysis-treated wastewater water. The cake resistance depends on size of particles and its porosity which is large in thermolysistreated wastewater.
Fig. 5 Settling of sludge at optimum parameters

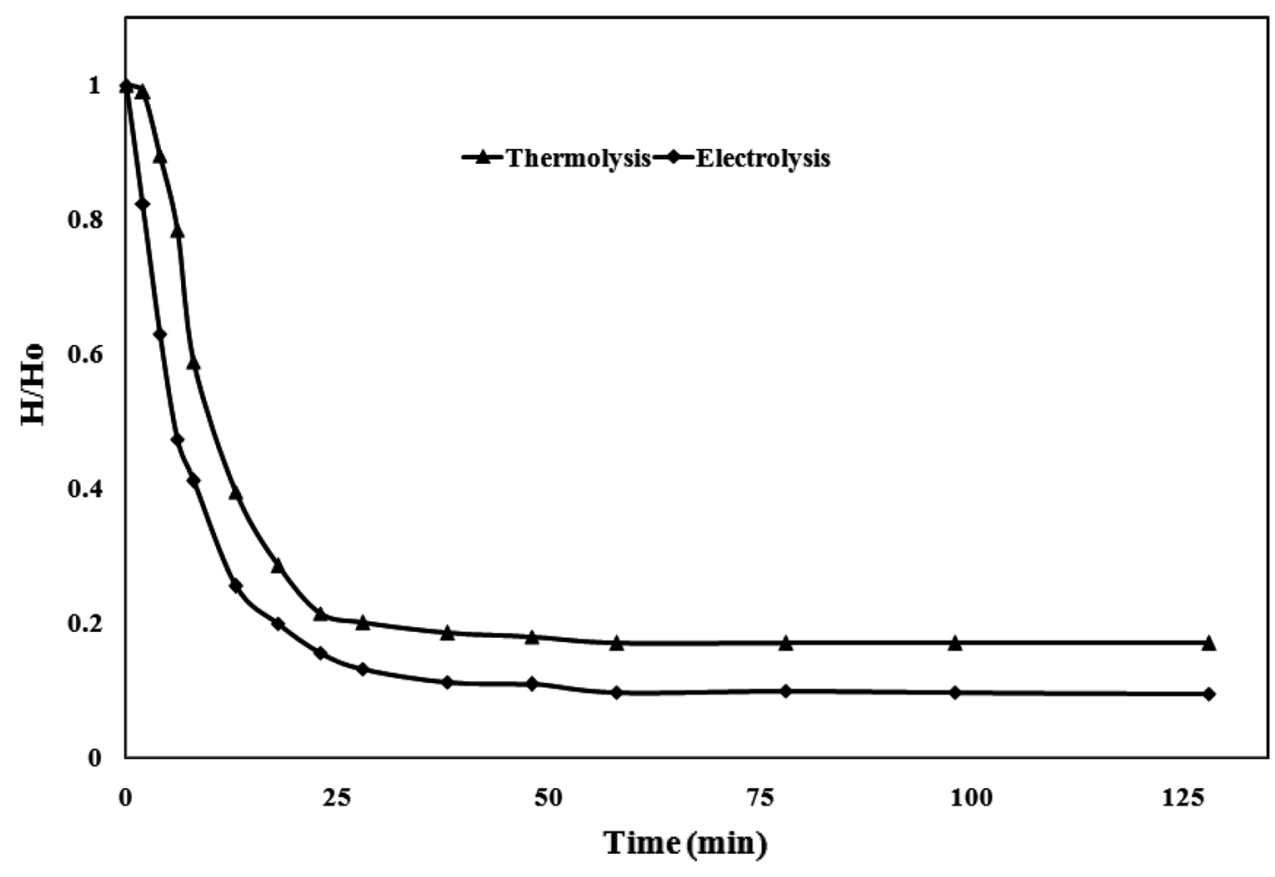

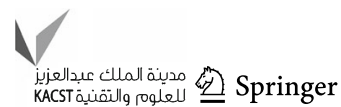


Table 2 Analysis of residue obtained after treatment

\begin{tabular}{llll}
\hline S. no. & Characteristics & Electrochemical & Thermolysis \\
\hline 1 & Weight of residue $\left(\mathrm{kg} / \mathrm{m}^{3}\right)$ & 3.5 & 2.21 \\
2 & Nature & Easy to grind, flaky & Easy to grind, small flaky \\
3 & Size (mm) & $0.05-0.5$ & $0.05-0.02$ \\
4 & Approximated drying period (h) & 08 & 05 \\
5 & COD removal (\%) & 81 & 80 \\
6 & Color removal (\%) & 84 & 82 \\
\hline
\end{tabular}

Fig. 6 Filterability of slurry at optimum parameters

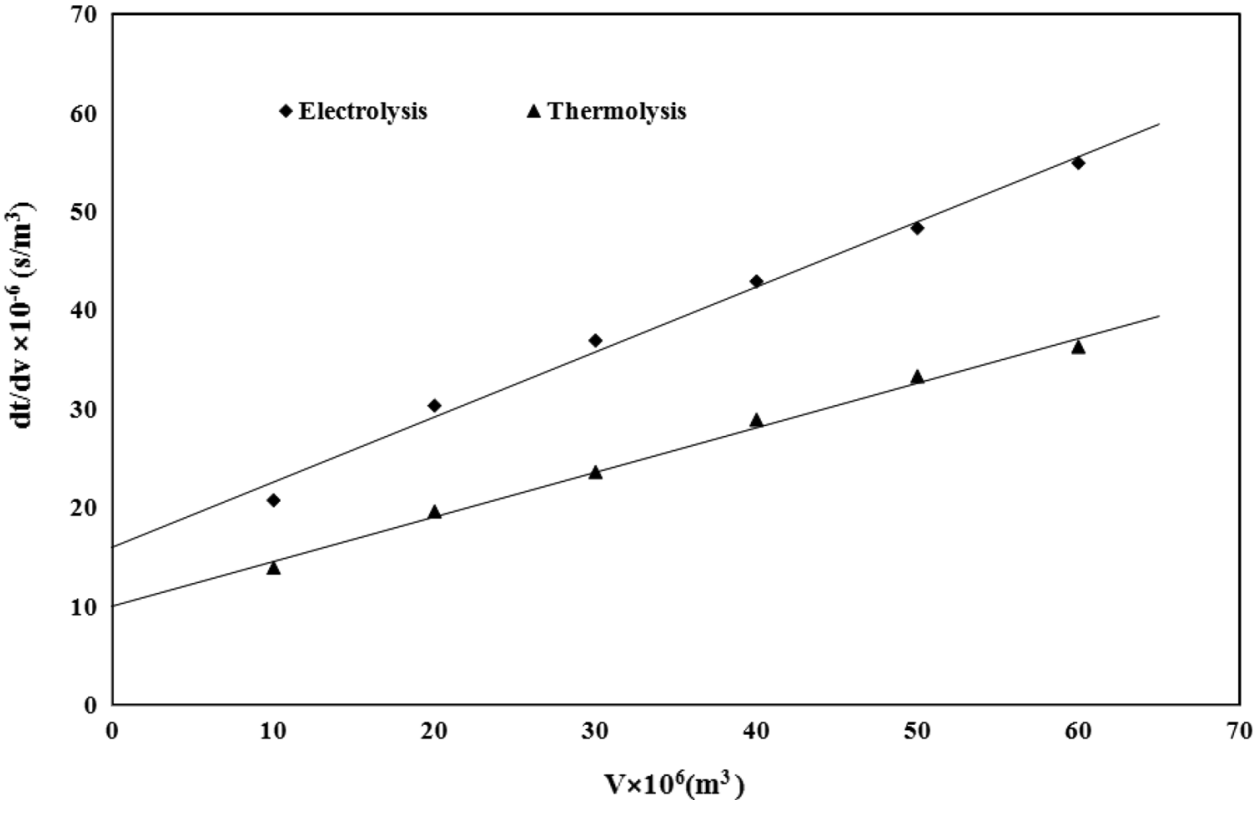

Table 3 Filterability of the treated waste water

\begin{tabular}{lllllll}
\hline S. no. & Initial $\mathrm{pH}$ & $K p \times 10^{-12}\left(\mathrm{~s} / \mathrm{m}^{6}\right)$ & $\beta \times 10^{-6}\left(\mathrm{~s} / \mathrm{m}^{3}\right)$ & $C\left(\mathrm{Kg} / \mathrm{m}^{3}\right)$ & $\alpha \times 10^{-14}(\mathrm{~m} / \mathrm{Kg})$ & $R_{m} \times 10^{-12}$ \\
\hline 1 & Electrolysis & 0.66 & 16 & 4.95 & 2.24 & 5.72 \\
2 & Thermolysis & 0.452 & 10.09 & 9.6 & 0.697 & 3.61 \\
\hline
\end{tabular}

\section{FTIR spectra}

The IR spectral studies of the treated samples (thermal and electrocoagulation treated) provide useful information on the presence of different functional groups. Sugar industry wastewater sample exhibits a broad band covering the region $3050-2700 \mathrm{~cm}^{-1}$ suggesting the presence of hydrogen bonded $v(\mathrm{OH})$ group. A broad band at $1400 \mathrm{~cm}^{-1}$ due to $\delta(\mathrm{OH})$ further suggests the presence of hydroxyl group, which is shown in Fig. 7a. A strong band at $1054 \mathrm{~cm}^{-1}$ confirms the presence of sulfate group possibly attached with metal ions. In addition, the presence of conjugated carbon-carbon bond is indicated by the presence of a medium-intensity band at $1262 \mathrm{~cm}^{-1}$. Dried sludge obtained after electrocoagulation treatment with iron electrode gave relative sharper but still broader band at $3200 \mathrm{~cm}^{-1}$. This is possibly due to breaking of the hydrogen bond and the presence of either free hydroxyl or coordinated hydroxyl group. This also suggests the precipitation of the component bearing hydroxyl group present in either complexed or free form. Absence of band due to sulfate group in this component indicates the removal of a 
Fig. 7 FTIR study of thermaltreated and electrochemicaltreated SIWW

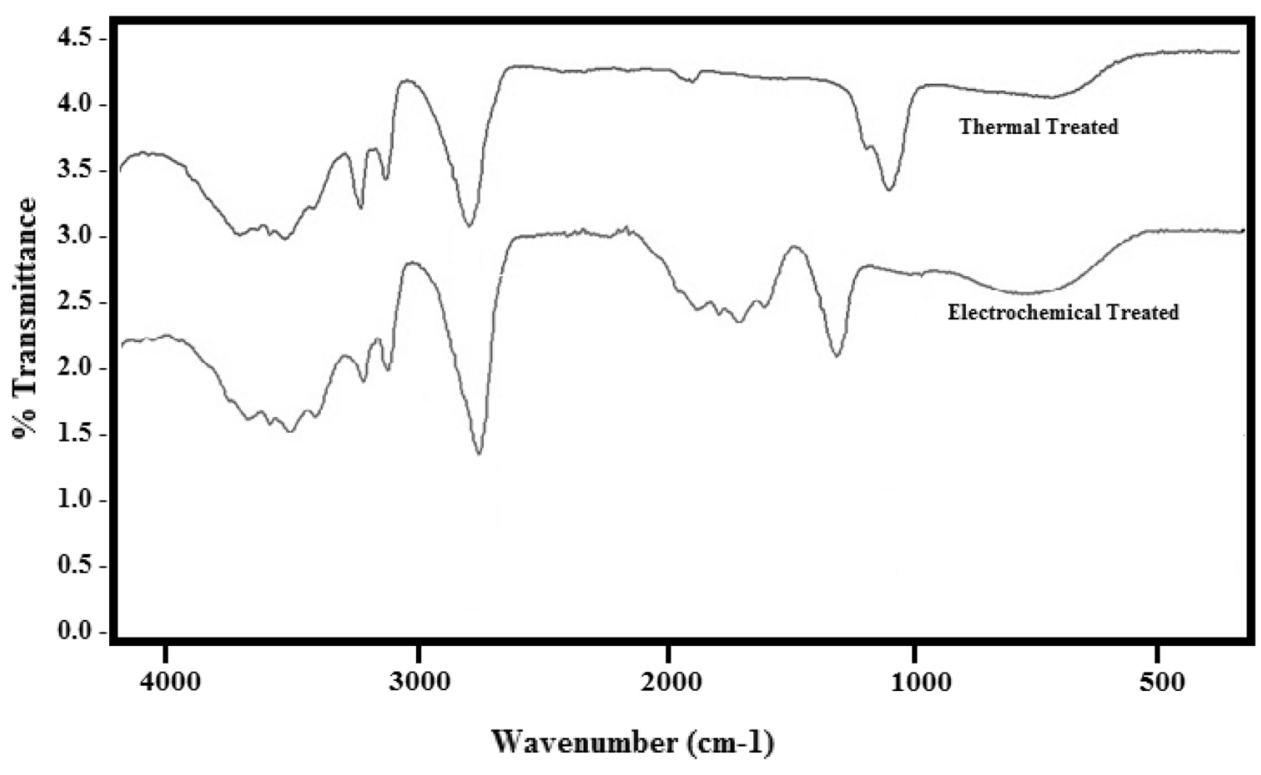

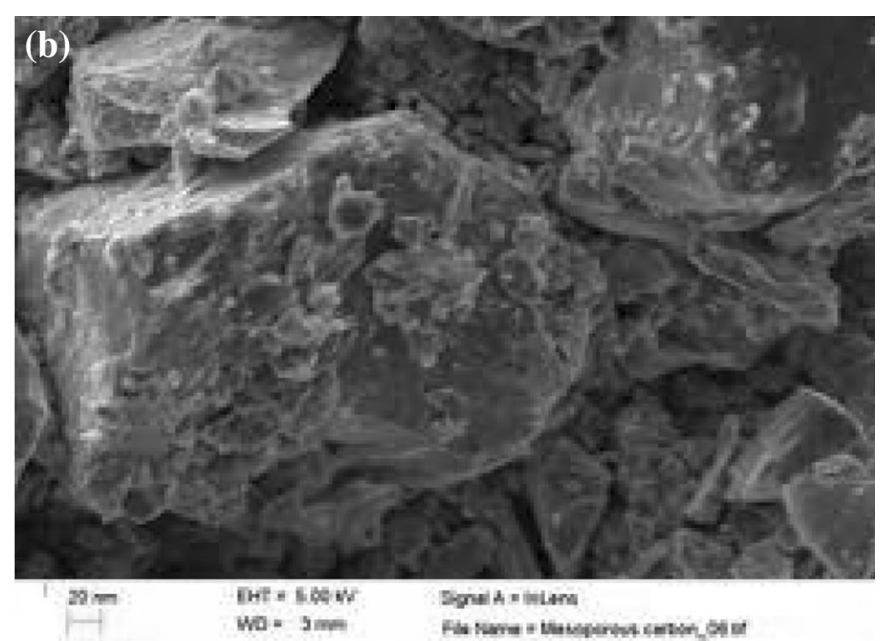

Fig. 8 SEM of a thermal-treated sludge b electrochemical-treated sludge

sulfate group as water-soluble component. The band at $986 \mathrm{~cm}^{-1}$ is possibly due to the presence of metal oxide, which is further supported by the appearance of two bands at 596 and $480 \mathrm{~cm}^{-1}$ due to $\mathrm{v}(\mathrm{M}-\mathrm{O})$, which are shown in Fig. $7 \mathrm{~b}$.

\section{Scanning electron micrograph}

The scanning electron morphology of the treated SIWW effluent (dried) is shown in Fig. 8a, b. Thermolysis treatment wastewater indicates high porosity, inhomogeneous surface and particles varying in shape. The particles looked like inorganic powders, several micrometers in size. The electrochemical-treated sludge is lumpy in nature and size varying from 25 to $150 \mu \mathrm{m}$. The electrolysis eliminates the various pollutants in the wastewater by oxidation, meanwhile the iron compound particles are formed including pollutants. When the iron compound particles agglomerate with each other, the organics may also be included into the aggregates.

\section{Conclusion}

It is concluded that when iron is used as a catalyst in thermolysis process, it shows $80 \%$ COD and $85 \%$ color removal at $4 \mathrm{~kg} / \mathrm{m}^{3}$ mass loading, treatment temperature $85^{\circ} \mathrm{C}$, treatment time $9 \mathrm{~h}$ and $\mathrm{pH}$ 6. When iron used as 
electrode in electrolysis process, it shows $81 \%$ COD and $84 \%$ color removal at $156 \mathrm{~A} \mathrm{~m}^{-2}$ current density, treatment time $120 \mathrm{~min}$ and anode consumption $0.7 \mathrm{~g}$ for $1.5 \mathrm{~L}$ wastewater was found. The settling of iron metal and iron catalyst had shown 90 and $75 \%$ of interface at $100 \mathrm{~min}$. The value of cake resistance $2.24 \times 10^{-14} \mathrm{~m} / \mathrm{kg}$ and filter medium resistance $5.72 \times 10^{-12}$ of thermal-treated wastewater is less as compared to metal-treated wastewater. FTIR result show the breaking of high molecular bond present in wastewater and dried sludge form in particles (thermolysis) and lump (electrolysis) nature. The outcome of research work is, in both treatments iron shows good performance for chemical oxygen demand and color removal. If both treatments can be combined, the wastewater can be brought up to the discharge limit.

Open Access This article is distributed under the terms of the Creative Commons Attribution 4.0 International License (http:// creativecommons.org/licenses/by/4.0/), which permits unrestricted use, distribution, and reproduction in any medium, provided you give appropriate credit to the original author(s) and the source, provide a link to the Creative Commons license, and indicate if changes were made.

\section{References}

Adhoum N, Monser L (2004) Decolourization and removal of phenolic compounds from olive mill wastewater by electrocoagulation. Chem Eng Process 43:1281-1287

Aradhey A (2015) Sugar annual report: global agricultural information report. GAIN Report Number: IN4029

Behbahani M, Alavi Moghaddam MR, Arami M (2011) A Comparison between aluminum and iron electrodes on removal of phosphate from aqueous solutions by electrocoagulation process int. J Environ Res 5(2):403-412

Bradford MM (1976) Annual Biochemical 72:248-254

Chaudhari PK, Mishra IM, Chand S (2008) Effluent treatment for alcohol distillery: catalytic thermal pretreatment (Catalytic thermolysis) with energy recovery. Chem Eng J 136:14-24

Chen G, Chen X, Yue PL (2000) Electrocoagulation and electroflotation of restaurant wastewater. J Environ Eng 126:858-863

Deshpande AM, Satyanarayan S (2011) Toxicity evaluation of through fish bioassay raw bulk drug industry wastewater after electrochemical treatment. Iran J Environ Health Sci Eng 8(4):215-225

Essadki AH, Bennajah M, Gourich B, Vial C, Azzi M, Delmas H (2008) Electrocoagulation/electroflotation in an external-loop airlift reactor: application to the decolorization of textile dye wastewater: a case study. Chem Eng Process 47:1211-1223

Farajnezhad H, Gharbani P (2012) Coagulation treatment of wastewater in petroleum industry using poly aluminum chloride and ferric chloride. Int J Res Rev Appl Sci 13(1):155-160

Genther ON, Beede DK (2013) Preference and drinking behavior of lactating dairy cows offered water with different concentrations, valences, and sources of iron. J Dairy Sci 96(2):1164-1176
Gupta A, Garg SK (2014) Analysis of sugar industry effluents, its remediation and mathematical modeling. Int $J$ Inf Futur Res 1(11): $15-25$

Holt P, Barton G, Mitchell C (1999) Electrocoagulation as a wastewater treatment. The third annual australian environmental engineering research event. 23-26 November Castlemaine, Victoria

Indian Sugar Mill Association (2015) statics report on sugar production in India. New Delhi, India

Kobya M, Hiz H, Senturk E, Aydiner C, Demirbas E (2006) Treatment of potato chips manufacturing wastewater by electrocoagulation. Desalination 190:201-211

Kumar P, Prasad B, Mishra IM, Chand S (2008) Decolorization and COD reduction of dyeing wastewater from a cotton textile mill using thermolysis and coagulation. J Hazard Mater 153:635-645

Kumar P, Prasad B, Chand S (2009) Treatment of desizing wastewater by catalytic thermal treatment and coagulation. J Hazard Mater 163:433-440

Kushwaha JP (2013) A review on sugar industry wastewater: sources, treatment technologies, and reuse. Desalin Water Treat. doi:10. $1080 / 19443994.2013 .838526$

Liu H, Zhao X, Qu J (2010) Electrocoagulation in water treatment. In: Comninellis C, Chen G (eds) Electrochemistry for the Environment. Springer, New York, pp 245-262

MaCabe WL, Smith JC, Harriot P (1993) Unit operation of chemical engineering, 5th edn. McGraw-Hill, New York

Mahesh S, Prasad B, Mall ID, Mishra IM (2006) Electrochemical degradation of pulp and paper mill wastewater. Part 2. Characterization and analysis of sludge. Ind Eng Chem Res 45(16):5766-5774

Sahu OP, Chaudhari PK (2015) The Characteristics, effects, and treatment of wastewater in sugarcane industry. Water Qual Expo Health. doi:10.1007/s12403-015-0158-6

Saranraj P, Stella D (2014) Impact of sugar mill effluent to environment and bioremediation: a review. World Appl Sci J 30(3):299-316

Shivayogimath CB, Jahagirdar R (2013) Treatment of sugar industry wastewater using electro coagulation technique. Int J Res Eng Technol 1(5):262-265

Tripathi GD, Javed Z, Sirohi S, Tyagi PK (2014) A biotechnological approach for treatment of sugar industry effluents: a review. Asian J Biochem Pharm Res Issue 3(4):293-297

Ulucan K, Kabuk AK, Ilhan F, Kurt U (2014) Electrocoagulation process application in bilge water treatment using response surface methodology. Int J Electrochem Sci 9:2316-2326

Upadhyay AP, Mistry NJ (2012) Feasibility of combined Fenton \& coagulation method for the treatment of pesticides waste water. Int J Eng Res Technol 1(3):115-125

Verma S, Prasad B, Mishra IM (2011) Thermochemical treatment (thermolysis) of petrochemical wastewater: COD removal mechanism and floc formation. Ind Eng Chem Res 50(9):5352-5359

Vinodha S, Carmerego D, Jegathambal P (2012) Comparison of Fe and $\mathrm{Al}$ Electrodes in the treatment of Blue Ca Dye effluent using electro coagulation process. Int $\mathrm{J}$ Eng Sci Technol 4(5):2188-2196

Vogel AI (1958) A text book of quantitative inorganic analysis, 3rd edn. Longman, London

Yadav A, Rani J, Daulta R (2014) Physico-chemical analysis of treated and untreated effluents from sugar industry. J Environ Human 1:113-119 